\title{
On the Construction of Three-dimensional material in foreign language teaching
}

\author{
Juan Chen
}

\author{
Foreign Language Dept., Yichun University, Jiangxi, China \\ tobefirstchen@163.com
}

Keywords: construction; curriculum construction; three dimensional material

\begin{abstract}
With further development and popularization of the multimedia technology and network technology, more and more people, especially for foreign language teachers and learners will be aware of the importance of network in the foreign language teaching and learning. The Construction of three-dimensional material of college is the inevitable trend of the modernization of foreign language teaching curriculum construction. This article mainly analyzes the problems and solutions that the construction of three-dimensional material is facing and summarizes the key elements involved in its development.
\end{abstract}

\section{Introduction}

Course construction is the key to achievie the goal of Applied Talents, one of the main elements of the program is the construction of the materials. Textbooks are important carriers of educational idea, teaching content, teaching methods and means, Textbooks are also the concrete manifestation of the achievements of the teaching contents and curriculum system reform.

In the era of knowledge economy, the fast update rate of information and knowledge has beyond people's imagination. With the continuous development and progress of society, rapide development of multimedia technology and computer network technology led to the rapid development of modern educational technology, causing profound changes in the field of course teaching, and have brought far-reaching impact on teaching methods and organizational forms.

With the rapid development of information technology, the traditional teaching concepts, models, methods and tools are undergoing great changes, while teaching content and form is also in process of changing, the traditional paper-based forms are challenged by the three-dimensional textbook, which intergraed with electronics, video, books and network. About the three-dimensional materials, the argument abroad has similar version, such as intergrated textbook, leaming/study package ect.

\section{Theoretical Basis}

According to the philosophy of “universal connexion principle”, teaching activities are not isolated, nor is it the same level, and it must change with the times, to meet the needs of the times. Currently we are in the information age, the computer as the core of the IT is used in various industries.

Cognitive linguistics considers that language learning is a complex process, need to call the physiological and mental activity function, it is a cognitive process of feeling the strange world of language environment and drivering communication behavior. Therefore,we need to let learners through a variety of stimulus, produce effective experience, have a reaction in foreign language learning, feeling and action process. ${ }^{[1]}$

Since the number of college students in China and the rapid growth in the relatively limited teaching resources, make full use of the multimedia, network technology brings the development opportunity, the new teaching mode.has become a good classroom teaching mode to improve the university foreign language teaching. 


\section{The Basic idea of Three-dimensional Material}

In China, the concept of three-dimensional materials was proposed relatively late, this is a new teaching concept proposed in the country over the past decade..It was first proposed by Higher Education Press, and was put into practice. Today, three-dimensional material is speeding up the pace of construction, not only in colleges but also in middle schools, it has grown from a single textbook materials, developped to printing materials, audio and video products, multimedia courseware, virtual reality teaching and other network resources.

Three-dimensional construction material is not simply the accumulation of existing resources, but effective design of instructional resources. On the basis of the existing forms, expression of the media and content is not a problem, the effective integration of resources is the primary point of design attention. With the construction of the campus network, advanced technology and first-class facilities, if these facilities can not be used efficiently for teaching service, will become a kind of decoration, and can not maximize its role.

\section{The Development of Three-dimensional Teaching Material}

The Materials in the Form of Three-dimensional. The construction of three-dimensional material is manifested in the form of three-dimensional carrier of materials. Paper textbooks is still the basic teaching material, it should be compiled with strenuous efforts. In the preparation of teaching materials, under the guidance of the basic requirements of the Ministry of Education Curriculum Steering Committee to the development of, comply with the direction of the reform of the teaching curriculum, based on the actual institutions, textbooks should focus on practical and effectiveness, focus on the cultivation of students' quality and overall ability; scientific and systematic reflect the interaction and developing law of knowledge of the discipline.

Three-dimensional Teaching Content. Reform of teaching content is always one of the central problems of the materials construction. In building materials, we adhere to highlight Applied Talents, follow the principle of focusing on the systematic development of knowledge and the gradual combination of curriculum knowledge, contact with the overall optimization point of view, appropriately integrating and refining teaching content, and focusing on the teaching content.

Three-dimensional teaching material is divided into several modules, the students can independently choose learning modules into different areas of study, according to their interests and learning progress. ${ }^{[2]}$ Dimensional teaching system basically includes: student's book, workbook, synchronous hearing or reading materials, teacher's book, teacher's CD, self-learning CD-ROM, website, test database, videos, tapes and so on. With the advent of technology development and new demands, some forms such as video tapes will be phased out, while some new forms such as adaptive test database appears, so three-dimensional teaching should be a dynamic concept, with different times, connotation of three-dimensional material may be different in different publishing house. To choose which form as specific material, it depends on the object and environment of the user.

Three-dimensional Material Usage. Instructional design system is the use of communication theory, learning theory, system theory and teaching theory, is the process of the system convert teaching principles into teaching plans and teaching materials. ${ }^{[3]}$ The center is to solve the problem of what to teach and how to teach. Instructional design system is the different levels of learning and teaching system, which includes promoting student's learning content, resources, conditions, methods and activities. Specifically, it can be teaching resources, used directly in the teaching process, to complete certain objectives., it may also be an embodiment of standards and course design, may also be a unit, a lesson design and planning. according to the teaching of the scope of the problem, different instructional design size accordingly with different application level, and can be summarized into three levels. 
About three-dimensional design of material for each component in teaching, at this level, teachers need to use the material, such as media, network and other products, to design the precise teaching process.

Activities designed in each teaching unit. At this level, mainly based on the requirements of the training objectives of the course, teachers design under the existing teaching facilities and resources for teaching, from the design point of view, mainly around the classroom, from the functional point of view of teaching, mainly for specific units, specific tasks, content selection and design process. In three-dimensional material development, it need to learn from this level of instructional design. ${ }^{[4]}$

\section{Other Notable Problems}

With the development of the curriculum reform and teaching reform, reduction in class hours has become a trend. At the same time, because of the limited class time, we must make full use of the extra-curricular time, increase the students' self learning time, develop personalized education space, in order to ensure the quality of personnel training.

To enable students to accumulate the experience of study, the process of personal experience to explore knowledge, students should be in a close to real learning environment to carry out learning activities, to accomplish specific tasks of each stage, first of all teachers should create such a learning environment for students, let their role from participants transit to the core members of activities of the the research study. ${ }^{[5]}$ Due to limited space, the traditional paper textbooks, can only explain situational events under normal circumstances, unable to create a real sense, students are easily to ignore this part. The three-dimensional materials as a combination of a variety of media, it can give a detailed description of the specific details of the task context, let learners explore in practical activities, and give timely help when students encounter difficulties

The full range construction of three-dimensional teaching material will promote the transformation of teaching idea of teachers, improve teaching methods and teaching level; accelerate the development of advanced application of the teaching method and the use of modern teaching methods, improve the teaching effect; promote the continuous optimization of the teaching reform of the teaching material construction, give better service to teaching content and course system, to create more excellent teaching and learning environment for the cultivation of applied talents.

\section{Summary}

The program design and language teaching closely integrated, as university foreign language teachers, we should improve our level of computer application, so as to cater to the needs of the times. The management of college personnel, should create a good environment to encourage teachers and students actively involved in teaching research, make the university foreign language learning into a virtuous cycle.

To sum up, strengthening college foreign language teaching dimensional construction has great significance in enhancing students' interest in learning, developing independent learning and improving teaching effectiveness. But the construction of three-dimensional material is a huge system engineering, we can not be greed, it must be carried on with a step-by-step approach. From the point of view that we should strive to develop teaching needs for different study subjects, at the same time, it should continue to reflect on teaching practice.

\section{References}

[1] Cheng yaping. College English teaching practice with the guidance of three-dimensional teaching method, joural of Tonghua teacher's college, 2006(3), pp. 133- 135.

[2] Zhao wanli. Further understanding of the three-dimensional teaching of English, University 
English teaching reform background, Education and Vocation,2009(36), pp.104-105.

[3] Liu ming, Hu jiasheng. Analysis of design concept and requirements of multi modal university foreign language audio-visual teaching material, Computer-assisted Foreign Language Education, 2011(02), pp. 3-8.

[4] Xu hong. Multi dimension on stereoscopic teaching material construction, China Electric Power Education,2008,(11),pp.79-80.

[5] Tan jie.Thinking Deeply About the Issue of the Construction of Three-dimensional Textbook in College English Curriculum Construction,Journal of Nanchang Normal University,2014,(6), pp.155-157. 